\title{
The Influence of Affective Brand Experience Dimension on Brand Equity of the Smartphone Millennial Users in Malaysia
}

\author{
Iman Khalid A-Qader, Azizah Binti Omar \\ University Sains Malaysia, Penang, Malaysia \\ Mohammad Rabiul Basher Rubel \\ Stamford University, Dhaka, Bangladesh
}

\begin{abstract}
This study intends to highlight the power of affective brand experience dimension and link how it can influence brand equity of smartphone users in Malaysia. Measurement items for affective brand experience dimension and brand equity were developed by integrating existing literature and qualitative in-depth interviews with students who own and use a smartphone. Therefore, 359 usable questionnaires were returned. Data were analyzed using PLS-SEM to test the influences of affective brand experience dimension on brand equity. The study found that affective brand experience dimension is an important factor influencing brand equity of smartphone users in Malaysia. The study provides evidence that the affective brand experience dimension positively influences brand equity. The distinctive contribution of this research is that it examines the influence of affective brand experience dimension on customer-based brand equity in the context of smartphone brands in the Malaysian emerging markets. Such work is essential in understanding the importance of experiential marketing in an emerging economy such as Malaysia for building a strong smartphone brand.
\end{abstract}

Keywords: affective brand experience dimension, brand equity, millennial generation

\section{Introduction}

Brand experience has attracted a lot of attention in marketing practice. Marketing practitioners have come to realize that understanding how consumers experience brands is critical for developing relevant marketing strategies for goods and services (Davis, 2009). In marketing, appropriate and relevant branding can result in higher sales of not only one product, but also on other products associated with that brand (Lassar, Mittal, \& Sharma, 1995). A brand refers to the personality of a company that identifies a product, service, or company through name, term, sign, symbol, design, or combination of them and how it relates to customers (Aaker, 1991; Keller \& Lehmann, 2006). Hence, a brand is the person personality that identifies a product, service, or company (name, term, sign, symbol, design, or combination of them) and how it relates to customers. Hence,

\footnotetext{
*Acknowledgments: The authors acknowledge the Short Term Grant provided by Universiti Sains Malaysia, Penang [Grant no: 304/PMGT/6313042] that has resulted in this article.

Iman Khalid A-Qader, lecturer, School of Management, University Sains Malaysia, Penang, Malaysia.

Azizah Binti Omar, associate professor, School of Management, University Sains Malaysia, Penang, Malaysia.

Mohammad Rabiul Basher Rubel, associate profesor, Department of Business Administration, Stamford University, Dhaka, Bangladesh.

Correspondence concerning this article should be addressed to Iman Khalid A-Qader, School of Management, University Sains Malaysia, Penang, 1180, Malaysia.
} 
under the experiential notion in marketing, the psychological aspects are distinguished so for example: brand associations like thoughts, feelings, perceptions, images, experiences, beliefs, attitudes, and so on that become linked to the brand from the experiential aspect. The experiential aspect consists of the sum of all points of contact with the brand and is known as the brand experience. Hence, brand experience is a brand's action perceived by a person (Ha \& Perks, 2005).

Since, global marketplace today is all about how consumers feel, relate, and act. Therefore, the human interaction is becoming a necessary component in providing the necessary encounters for generating memorable experiences (Atwal \& Williams, 2009). As a result, competition is fierce among marketers in which principles and actions of traditional marketing are no longer effective and appealing among consumers. Marketers wanted to find new opportunities to attract customers, and that is when the notion of experiential marketing came into view. Holbrook and Hirschman (1982) were the first pioneers in introducing the notion of experience in the field of consumption and marketing. Twenty years later, this notion of experience has gained solid recognition and is considered essential for what it can contribute to marketing knowledge. Therefore, the notion of experience is considered to be a pillar of the so called experience economy and experiential marketing (Grundey, 2008).

Past studies have shown the impact of brand experience both directly and indirectly on short-term consequences, such as satisfaction and loyalty, the question arises that whether brand experiences affect customer lifetime value (Brakus, Schmitt, \& Zarantonello, 2009), that is, can brand experiences build brand equity? Thus, reviewing and conceptualizing the dimensions of brand experience and linking how these dimensions can influence brand equity of smartphone users among the millennial generation is in great demand.

\section{Literature Review}

\section{Brand Experience}

According to Brakus et al. (2009), most of the researches on experiences to date have focused on utilitarian (usefulness) product attributes and category experiences, not on experiences provided by brands. When consumers search for shop for consumer brands, they are exposed to utilitarian product attributes. However, consumers are also exposed to various specific brand-related stimuli, such as brand-identifying in the branding literature. Alsem and Kostelijk (2008) explained the concept of brand identity and defined it as a unique set of brand associations that a firm can create or maintain. It may involve a value-proposition with functional, emotional, or self-expressive benefits. However, brand associations are either tangible or emotional/symbolic or both. For example, colors (Bellizzi \& Hite, 1992; Gorn, Chattopadhyay, \& Dahl, 1997; Meyers-Levy, L. A. Peracchio, \& L. Peracchio, 1995), shape (Veryzer Jr \& Hutchinson, 1998), typefaces, background design elements (Mandel \& Johnson, 2002), slogans, mascots, and brand characters (Keller, 1987). The current study demonstrated that brand experience can be broken down into four dimensions (sensory, affective, intellectual, and behavioral), which are differentially evoked by various brands. Hence, this study adopts Brakus et al.’s (2009) conceptualization of brand experience.

Affective (FEEL) brand experience, dimension of brand experience. Affective experiences (FEEL) are defined by Schmitt (1999) as marketing appeals to customers' inner feelings and emotions, with the objective of creating affective experiences that range from mildly positive moods linked to a brand to strong emotions of joy and pride. In addition, the feel experiences are defined by Xu and Chan (2010) as the customers' perceptions of fun and pleasure. Consequently, the best relationships with customers are affective or emotional 
in nature and when companies succeed in not only satisfying certain needs but also making the interactions pleasurable, as a result, people are more inclined to stay loyal, even when a mistake takes place (Pine \& Gilmore, 1999). According to Kim (2003), emotional certainty indicates that the certainty associated with an emotion can affect information. It has also been confirmed in research that consumers look for and buy emotional experiences around what has been bought and no longer buy products and services alone (Ekström \& Brembeck, 2004; Ratneshwar \& Mick, 2005).

\section{Brand Equity}

According to Atilgan, Aksoy, and Akinci (2005), one of the most popular and potentially important marketing concepts which have been extensively discussed by both academicians and practitioners over the past decade is brand equity. One of the reasons for its popularity is its strategic role and importance in gaining competitive advantage and in strategic management decisions. The competitive advantage of firms according to Farquhar (1989) for brands to have high equity includes the opportunity for successful extensions, resilience against competitors' promotional pressures, and creation of barriers to competitive entry which is considered to be critical in developing marketing strategies for goods and services. Brand equity, when correctly and objectively measured, is an appropriate metric for evaluating the long-run impact of marketing decisions (Simon \& Sullivan, 1993b). Positive customer-based brand equity, in turn, can lead to greater revenue, lower costs, and higher profits; and it has direct implications for the firm's ability to command higher prices, customers' willingness to seek out new distribution channels, the effectiveness of marketing communications, and the success of brand extensions and licensing opportunity (Keller, 2003).

Generally, there are several other definitions of brand equity from different perspectives; Farquhar (1989) defined brand equity as the "added value" with which a given brand endows a product. While Aaker (1991) defined brand equity as a set of brand assets and liabilities linked to a brand, its name and symbol, which add to or subtract from the value provided by a product or service to a firm or to a firm's customers. In addition, Srivastava and Shocker (1991) defined brand equity as the aggregation of all accumulated memories in the extended minds of consumers, distribution channels, and influence agents, which will enhance future profits and long-term cash flow. Furthermore, Wood (2000) argued that brand equity involves the value added to a product by consumer's associations and perceptions of a particular product. While Simon and Sullivan (1993a) defined brand equity as the incremental cash flows which accrue to branded products over unbranded products. Moreover, Keller (1993) defined customer based brand equity as the differential effect of brand knowledge on consumer response to the marketing of a brand. However, this study conceptualizes brand equity as the overall utility and value that customers place in a brand when compared to its competitor (Aaker, 1991; Boo, Busser, \& Baloglu, 2009; Yoo \& Donthu, 2001).

The relationship between brand experience and brand equity. Past studies have studied brand experience in relation to different variables such as satisfaction and loyalty (Brakus et al., 2009). However, other researchers studied brand experience in relation to brand equity by including other variables influencing brand equity for example, Berry (2000) argued that customer's experience with a company influenced brand equity through brand meaning which refers to the customer's dominant perceptions of the brand, and what immediately comes to the consumers mind if a certain brand is mentioned. Therefore, as customers experience the company's total products these experiences become influential because customer's experience-based beliefs are powerful, because customers tend to rely on their own experiences more than relying on advertising (Berry, 
2000). Furthermore, Cobb-Walgren, Ruble, and Donthu (1995) studied brand equity in relation to brand preference and purchase intention, and found that brands with higher equity generated significantly greater preferences and purchase intentions. Moreover, according to Krishnan (1996), consumers learn about products from a variety of sources. One reasonable position according to Aaker and Biel (2013) is that for various reasons, associations from sources are more important components of equity, since they lead to differences in associations' strength. One distinction in sources is between direct experience (e.g., trial and usage) and indirect experience with a brand (e.g., advertising and word of mouth). Compared with indirect experiences, associations based on direct brand experiences are likely to be more self-relevant (Burnkrant \& Unnava, 1995), and held with more certainty (Smith \& Swinyard, 1983). Hence, a brand that has high proportion of associations based on direct experience should be in a relatively strong position and posse's high equity. Furthermore, Xu and Chan (2010) found that hotel guests establish their brand knowledge through direct and indirect experiences. Hence, they conclude that a better understanding of how these experiences contribute to brand equity has important implications for brand managers. Aaker and Biel (2013) considered creative advertising as a powerful tool for building strong brands; they also stressed the urgency to advance marketer's commitment to the importance of brand equity.

Moreover, Burnkrant and Unnava (1995) found that increasing self-referencing (e.g., one's own personal experience) increases message elaboration and can increase message persuasion when message arguments are strong. According to Ambler (1997), brand equity is made up of memories of different kinds. Which are identified by Rose (1993) as procedural or reflexive (responsive) memory that records how things are done. It includes programmed behavior patterns (habits) and is largely unconscious leading to the alarms, which proved unfounded about the possibility of subliminal advertising declarative memory takes two forms: semantic, which records meanings and associations; and episodic, which records facts and events. Declarative memory can be cognitive (thinking-related) and affective (feeling-related). Awareness is cognitive, as the knowledge concerning brand's functional performance characteristics and price. Attitudes towards the brand are primarily affective, in another words, the concept of evaluation in emotion links emotion to "attitude" in that attitude measures reflect an evaluation (O’ Shaughnessy, 1992).

In addition, Smith and Swinyard (1983) studied the role of direct versus indirect experience on attitude-behavior consistency, their results show that when attitudes are based on direct experiences, purchase behavior was predicted very well. Therefore, the above literature obviously stated that brand experiences arise in a variety of settings, and these experiences can influence behavior which in turn can affect brand equity. However, recent studies suggest that customers are inclined to choose one brand over others for its experiential benefits, this indicates the possibility of a direct causal relationship between brand experience and its ability to generate consumer-based brand's equity (Hultén, Broweus, \& Van Dijk, 2009; Ratneshwar \& Mick, 2005; Zarantonello \& Schmitt, 2010). Nonetheless, a limited attempt was made in the past to identify some of the possible consequences of brand experience such as satisfaction, loyalty, and brand commitment (Brakus et al., 2009; Iglesias, Singh, \& Batista-Foguet, 2011; Morrison \& Crane, 2007; Zarantonello \& Schmitt, 2010). Furthermore, past studies failed to incorporate the most important marketing construct such as brand equity as a potential outcome of brand experience in a single model. Therefore, this study will shed the light on the structural relationship between affective brand experience dimension and brand equity.

The pivotal role of brand experience in the millennial generation. This age group grew up with the worldwide web, the latest technology, and numerous communication channels, ranging from cell phones to 
Facebook and Twitter, leaving Generation X and the more elderly far behind (Williams \& Page, 2010). However, the millennials have been targeted with extravagant advertising and commercials since a very young age; as a result, this generation is quite suspicious towards all marketing campaigns. Furthermore, Williams and Page (2010) suggested that many names have been given to Generation Y, they are referred to as: Millennials, Echo Boomers, Why Generation, Net Generation, Gen Wired, We Generation, Dot Net, Next Generation, Nexters, First Globals, iPod Generation, and iY Generation. The millennials are born between 1982 and 2000, and are the children of the baby boomers (persons born between 1946 and 1964) (Lancaster \& Stillman, 2010). This group includes several age cohorts: tweens aged between 10 and 12, teens aged between 13 and 18, and young adults aged between 19 and 33, their purchasing power is \$733 billion ( Kotler \& Armstong, 2012). Hence, the millennials are a huge attractive market; they grew up in a time of immense and fast-paced change including virtually full employment opportunities for women, dual-income households as the standard, wide array of family types seen as normal, significant respect for ethnic and cultural diversity including a heightened social awareness, and computers in the home and schools.

In Malaysia, the millennials make up approximately 62\% of the Malaysian workforce (PWC, 2009). The millennial generation grew up in the age of technology where every child grew up with a computer in the hands. Unlike past generations, the technological advances in the past decade have put a multitude of choices at the fingertips of the millennials, the wealth of information available in seconds from the Internet, hundreds of television stations to choose from, and a different shopping center every 10 miles have given the millennial members the notion that if they do not get what they want from one source, they can immediately go to another. In addition, the millennials are bold, bash, facebooking, iPhone lovers, and multi-taskers, tweeting Blackberry in one hand, an ear to their iPhone, and an eye on the latest download.

Given the selective nature of the millennial generation, Williams and Page (2010) concluded that this generation values "experience". Therefore, by getting to know the millennial high-tech savvy consumer, smartphone companies can learn how to meet the customers' expectations by providing positive brand experiences to the millennial smartphone buyers. Consumers will continue to purchase the same brand of smartphone after they have had a positive brand experience with a certain smartphone brand. As a result, positive brand experiences will enable smartphone companies to successfully build strong brand experience among the millennial population which is estimated to account for two billion customers worldwide. The sheer size of this generation and their spending power require companies, producers, marketers, and advertisers to reconsider their business and marketing models ( Rendell, Linde, \& Yildirim, 2011).

\section{Research Hypotheses}

The proposed hypotheses for this study were formulated based on literature review from previous studies, explaining the relationship between affective brand experience and brand loyalty.

\section{The Relationship Between Affective Brand Experience Dimension and Brand Equity}

Affective experiences (feel) are defined by Schmitt (1999) as marketing appeals to customers' inner feelings and emotions, with the objective of creating affective experiences that range from mildly positive moods linked to a brand to strong emotions of joy and pride. In addition, the feel experiences are referred to by Xu and Chan (2010) as the customers' perceptions of fun and pleasure. However, Zaltman (2003) argued that the tangible attributes of a product or service have far less influence on consumer preference than the subconscious sensory and emotional elements derived from the total experience. According to Kim (2003), 
emotional certainty indicates that the certainty associated with an emotion can affect information processing. However, Forgas (1981) found that peoples' mental representations are largely dominated by the affective characteristics of episode stimuli rather than by their actual descriptive features. In addition, Niedenthal and Halberstadt (2001) explained that effect often determines the use and evaluation of categories of stimuli. It has also been confirmed in research that consumers look for and buy emotional experiences are around what has been bought and no longer buy products and services alone (Ekström \& Brembeck, 2004; Ratneshwar \& Mick, 2005). In addition, findings of Zarantonello and Schmitt (2010) indicated that respondents with the highest scores on the affective dimension are consumers who look for a brand experience that provides them with emotional appeals. They attach more importance to the emotions that brands are able to generate in them. Therefore, Malhotra, Dash, Kumar, and Chandra (2013) explained that the more a brand induces positive experience, the more satisfied a customer will be with the brand. Consequently, affective brand experience covers the mood, emotions, and feeling of customer toward the brand. The mood, emotion, and feeling of customer toward the brand positively influence brand association and perceived quality of service. Consequently, positive brand experience results in strong brand equity. Therefore, this study hypothesizes that:

H1: Affective brand experience will positively influence brand equity of smartphone users among the millennial generation.

\section{Methodology}

\section{Sample}

A total of 450 questionnaires were distributed to the target respondent of the present study. The questionnaires were distributed to full time undergraduate students from four public universities located in the northern region of Malaysia. Data collection was done via questionnaires which were distributed to the allocated quota of number of students from the four public universities namely: Universiti Pendidikan Sultan Idris, University Sains Malaysia, University Malaysia Perlis, and University Utara Malaysia. Table 1 summarizes the questionnaire distribution among the four listed public universities.

Table 1

\section{List of Universities and Questionnaire Distribution}

\begin{tabular}{lllll}
\hline Name of university & $\begin{array}{l}\text { Number of target } \\
\text { respondents }\end{array}$ & $\begin{array}{l}\text { Number of } \\
\text { questionnaires } \\
\text { distributed }\end{array}$ & $\begin{array}{l}\text { Number of usable } \\
\text { questionnaires }\end{array}$ & Response rate \\
\hline Universiti Pendidikan Sultan Idris & 83 & 83 & 65 & $78 \%$ \\
Universiti Sains Malaysia & 180 & 180 & 152 & $84 \%$ \\
Universiti Malaysia Perlis & 46 & 46 & 39 & $85 \%$ \\
Universiti Utara Malaysia & 141 & 141 & 103 & $73 \%$ \\
Total & 450 & 450 & 359 & $80 \%$ \\
\hline
\end{tabular}

The total number of distributed questionnaires was 450. However, 402 questionnaires were returned, and only 43 out of 402 questionnaires returned are unusable due to incompleteness. The final usable questionnaires were 359 which accounted for 80\% response rate. Based on Hair, Black, Babin, and Anderson's (2010) general rule, sample size should be at least five times as many observations as the number of variables to be analysed in the study and the more acceptable size would be 10 to 1 . While, Hoe (2008) suggested that a rule of thumb is that any sample size above 200 is sufficient for data analysis. However, in order to determine the sample size Sekaran and Bougie (2010) suggested that one rule of thumb sample size between 30 and 500 could be more 
effective for most researches conducted. Kline (2011) has suggested that a sample size should be between the range of 150 to 400 . In conclusion, the complete usable 359 questionnaires resulting in $80 \%$ response rate is sufficient for data analysis. Table 2 below provides a detailed summary of response rate.

Most of the respondents of this study are in the first year student in the undergrad level (44.8\%), whereas one third of the respondents came from both management (16.2\%) and economic and business (13.6\%). In terms of the original living state of the respondents, the highest number of respondents came from Sarawak (12.5\%) then Perak (11.4). Most common age group was found 18-25 years (100\%) and near half of this group fell into the age group of 20-23 years (51.5\%). In this research the majority of the respondents were female (61.3\%). More than half of the respondents came from the Malay ethnic group (57.7\%). More than half of the respondents' (60.2\%) monthly income found less than 1,000 RM and more than half of the respondent's income came from their parents (59.1\%). In the area of using smartphone, the result showed that the family members' recommendations are the main influential which comprises $44 \%$ of the total responses. In terms of respondents' number of years using a smartphone, the results of the study show that $4.2 \%$ of respondents have been using a smartphone for less than one year. While $85.2 \%$ of respondents have been using smart phones between one and four years, and $10.6 \%$ have been using smartphone for over five years. The result of the study also showed more than $40 \%$ respondents found suitability in using Samsung as the brand of their mobile. Therefore, the results of the study indicate that the majority of the millennial generation has been using a smartphone between one and four years.

\section{Measure}

Affective dimension of brand experience was adapted from Brakus et al.'s (2009) brand experience scale, using three items and adding two self-constructed items. Respondents will have to give answers to five items on a five-point Likert scale ranging from strongly disagree $=1$ to strongly agree $=5$. Whereas, measurement for brand equity was adapted from Buil, de Chernatony, and Martínez (2008) and Yoo and Donthu (2001), using seven-item brand equity scale which captures the four dimensions of overall brand equity (four items), perceived value (one item), brand personality (one item), and organizational associations (one item). For both, the dimension alpha value was found high, affective brand experience (0.81) and brand equity (0.91). A five-point Likert scale ranging from (1) strongly agree to (5) strongly disagree was employed to measure all the items representing each variable.

\section{Analysis and Results}

This study used the partial least square path modeling technique to analyze the collected data. PLS is also known as the variance-based structural equation model consisting of factor analysis, correlation, and regression. SPSS (Version 20) for Windows (SPSS, Chicago, IL) was employed to analyze the survey data to get the descriptive statistical output. Later, common method variance (CMV) was assessed to check the multicollinearity. When data are collected using a cross sectional survey method, CMV may be a problem (P. M. Podsakoff, MacKenzie, Lee, \& N. P. Podsakoff, 2003). To report this potential problem, Harman Single factor test was used. According to Podsakoff et al. (2003), common method variance arises in the dataset if: 1) a single factor emerges from a factor analysis of all survey items, and 2) a single factor accounts for most of the common variance existing in the data. Therefore, in this concern an un-rotated factor analysis conducted on all measurement items extracted six factors with eigenvalues larger than or equal one. In this study, total six factors accounted for $72.68 \%$ of the total variance and the first factor explains $29.88 \%$. While, a single factor 
did not account for most of the variance, thus this study pretends that the CMV was not the main problem in this study.

\section{Measurement Model}

In this stage of data analysis, both convergent and discriminant validity were assessed to examine the measurement model. Convergent validity was calculated by measuring reliability, composite reliability (CR) and the average variance extracted (AVE). Reliability of items was measured by each item's loading on its corresponding construct. A rule of thumb suggests that the item loading should exceed 0.50 or higher (Hair et al., 2010). In this study, two items from brand equity (BEQ $6=0.367$ and BEQ $7=0.484$ ) were deducted due to loading lower than the acceptable limit. In addition, CRs and AVEs are recommended to be 0.70 and 0.5 or higher, respectively (Gefen, Straub, \& Boudreau, 2000). Table 2 shows that both CR and AVEs exceeded 0.70 and 0.50 respectively.

Table 2

Item Loading, Scale Reliability, AVE and CR

\begin{tabular}{lllll}
\hline Constructs & Items & Loading & CR & AVE \\
\hline \multirow{4}{*}{ Affective dimensions } & ADIM 1 & 0.702 & 0.845 & \\
& ADIM 2 & 0.716 & & \\
& ADIM 3 & 0.761 & & \\
& ADIM 4 & 0.764 & 0.567 \\
Brand equity & ADIM 5 & 0.664 & & \\
& BEQ 1 & 0.723 & & \\
& BEQ 2 & 0.814 & & \\
& BEQ 3 & 0.819 & & \\
& BEQ 4 & 0.746 & & \\
\hline
\end{tabular}

Further, Fornell and Larcker's formula was used to assess the discriminant validity between constructs that the square root of the AVE for each construct should be higher than the correlations between these constructs and all other constructs (Chin, 2010). This study finds the square root of AVE of all the diagonal values of the constructs were higher than the off-diagonal ones. As shown in Table 2, the calculated value of AVE exceeds the intercorrelations of the diagonal constructs with the other off-diagonal constructs ensuring adequate discriminant validity. Therefore, the results of the analysis can reveal that the measurement model of this study fulfills adequate convergent and discriminant validity.

This study also assessed the Goodness of Fit (GoF) using the formula suggested by Tenenhaus, Vinzi, Chatelin, and Lauro (2005) and found the model had a large goodness of fit (GoF $=0.361)$. According to Wetzels, Odekerken-Schroder, and Van Oppen (2009), the value higher than 0.36 indicates global validation of the PLS model. In addition to evaluating the magnitude of the $R^{2}$ value as a criterion of predictive accuracy, researchers need to examine the Stone-Geisser's $Q^{2}$ value. This measure is an indicator of the model's predictive relevance. The $Q^{2}$ represents "a measure of how well observed values are reconstructed by the model and its parameter estimates” (Chin, 2010). For calculating predictive relevance, the stone-Geisser $Q^{2}$ was considered. In this regard, the value redundancy (Red) in $Q^{2}$ must be greater than zero (Chin, 2010). This study also fulfills the criteria and finds the value of the redundancy (Red: 0.113) acceptable. 
Table 3

Discriminant Validity Table

\begin{tabular}{lll}
\hline & ADIM & BEQ \\
\hline BEQ & 0.722 & \\
ADIM & 0.489 & 0.754 \\
Mean & 3.55 & 3.65 \\
SD & 0.671 & 0.614 \\
\hline
\end{tabular}

\section{Structural Model}

In analyzing the structural model, a bootstrapping method with 1,000 re-samples was deliberated to test for path significance (Chin, 1998a; 1998b). Table 4 and Figure 1 explain all the path relationships of the framework. In the direct relationship between the variables, affective brand experience to brand equity showed a significantly positive relationship and the values are $\beta=0.488, p<0.01$. Therefore, it can be said that affective brand experience is found to be an important predictor of the brand equity of the millennial smartphone users in Malaysia.

Table 4

Result of Partial Squares Path Analysis

\begin{tabular}{lllll}
\hline Path & Std. Beta & Std. error & t value & Decision \\
\hline Affective experience of brand dimension $>$ Brand equity & 0.488 & 0.045 & 10.88 & Supported \\
\hline
\end{tabular}

Notes. ${ }^{* *} p<0.01,{ }^{*} p<0.05$ (based on one-tailed test with 1,000 bootstrapping).

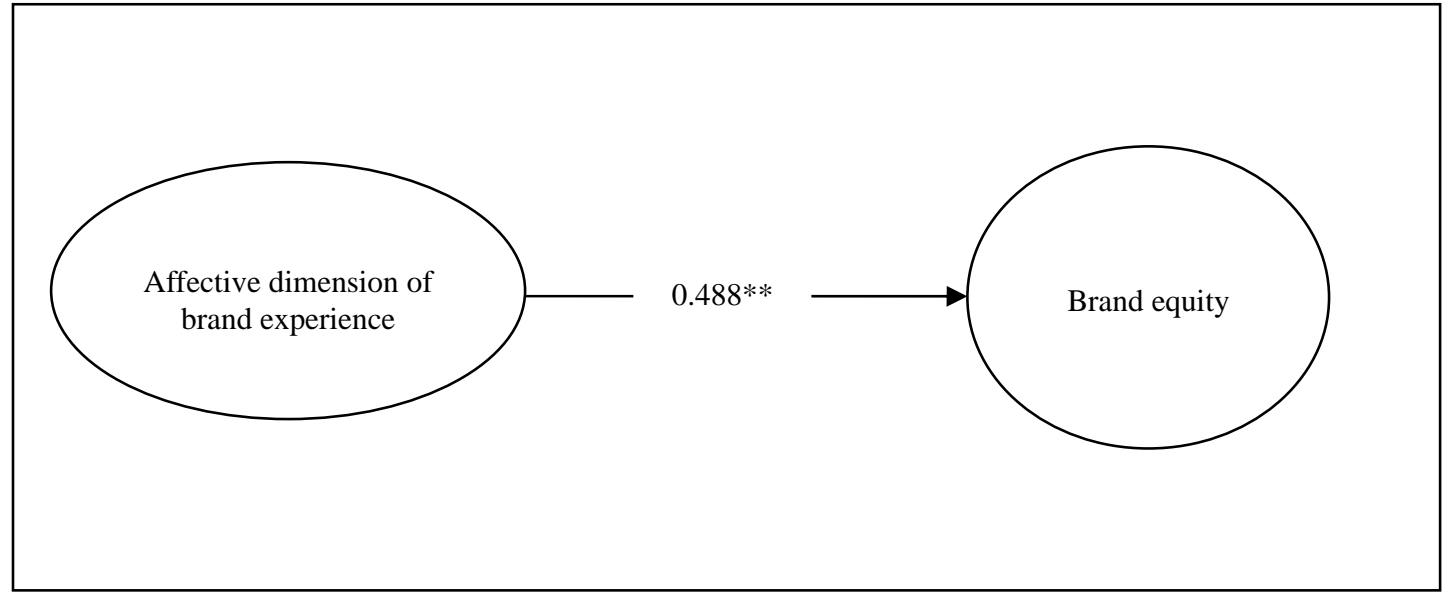

Figure 1. Structural model.

\section{Discussion}

The findings of the study indicated that affective brand experience dimension which consists of consumers' inner feelings and emotions has a strong influence on the millennial smartphone users in Malaysia. This indicates that the respondents of the study have strong emotions and feelings towards their smartphone. The strong emotions and feelings are evident in respondents revealing that they like using their smartphone brand, as it influences their emotions and they feel happy when using it. In addition, respondents are also proud of the brand they are using and they have fun using it. Thus, the results for affective brand experience dimension are in line with previous studies, conducted by Schmitt (1999), suggesting that the higher the brand appeals to customers' inner feelings and emotions, the stronger emotions of joy and pride evolve. These results are consistent with 
Zajonc (2000) who stated that the affective quality of the original input is the first element to emerge when people try to retrieve an object such as an episode, person, and piece of music, story, or name. As such, affective conviction about the brand would be a major element emerging when retrieving the memory associated with the brand, then to influence the loyalty formation process. The emotional linkage between brand and consumer has been proposed as important in building strong brands.

The results of this study are consistent with previous research of Zarantonello and Schmitt (2010), their findings indicated that respondents with the highest scores on the affective dimension are consumers who look for a brand experience that provides them with emotional appeals. They attach more importance to the emotions that brands are able to generate in them. In conclusion, Zarantonello and Schmitt (2010) explained that if a consumer likes a brand because it provides experiential gratification in various ways, he or she may be willing to buy it without further scrutiny. In addition, Malhotra et al. (2013) explained that the more a brand induces positive experience, the more satisfied a customer will be with the brand. Consequently, affective brand experience covers the mood, emotions, and feeling of customer toward the brand. The mood, emotion, and feeling of customer toward the brand positively influence brand association and perceived quality of service. Consequently, positive brand experience results in strong brand equity. Therefore, the result of this new finding contributes to the literature that affective brand experience dimension positively influences customer brand equity of the millennial smartphone users in Malaysia.

\section{Conclusions and Recommendations}

The main importance of this paper comes into view through: firstly, reviewing the influence of affective brand experience dimension on brand equity; secondly, shedding the light on the millennial generation which consists of two billion new customers worldwide, and makes up over $40 \%$ of the population in Malaysia, which makes them potential leaders, consumers, and users with great purchasing power that shape the country's social, economic, and political landscape in the future. The practical importance of this study comes into view through identifying how affective (feel) brand experience dimension can impact customer-based brand equity of smartphone brand. As a result, this study provides evidence that the affective brand experience dimension positively influences brand equity. The distinctive contribution of this research is that it examines the influence of affective brand experience dimension on customer-based brand equity in the context of smartphone brands in the Malaysian emerging markets. Such work is essential in understanding the importance of experiential marketing in an emerging economy such as Malaysia for building a strong smartphone brand. Consequently, smartphone companies should stress the emotional appeal of their offers to meet customers' expectations by providing the millennial buyers with smartphones that fulfill their needs. Consequently, consumers will continue to purchase or upgrade their smartphone of a particular brand. In conclusion, affective brand experience dimension is a strong predictor of high customer based brand equity which in turn can influence buying behavior of smartphone brands in Malaysia.

\section{References}

Aaker, D. A. (1991). Brand equity: Capitalizing on the value of a brand name. New York, NY: Free Press.

Aaker, D. A., \& Biel, A. L. (2013). Brand equity \& advertising: Advertising's role in building strong brands. San Francisco: Psychology Press.

Alsem, K. J., \& Kostelijk, E. (2008). Identity based marketing: A new balanced marketing paradigm. European Journal of Marketing, 42, 907-914. 
Ambler, T. (1997). How much of brand equity is explained by trust? Management Decision, 35, 283-292.

Atilgan, E., Aksoy, S., \& Akinci, S. (2005). Determinants of the brand equity: A verification approach in the beverage industry in Turkey. Marketing Intelligence \& Planning, 23, 237-248.

Atwal, G., \& Williams, A. (2009). Luxury brand marketing-The experience is everything! Journal of Brand Management, 16, 338-346.

Bellizzi, J. A., \& Hite, R. E. (1992). Environmental color, consumer feelings, and purchase likelihood. Psychology and Marketing, 9, 347-363.

Berry, L. L. (2000). Cultivating service brand equity. Journal of the Academy of Marketing Science, 28, 128.

Boo, S., Busser, J., \& Baloglu, S. (2009). A model of customer-based brand equity and its application to multiple destinations. Tourism Management, 30(2), 219-231.

Brakus, J. J., \& Schmitt, B. H., Zarantonello, L. (2009). Brand experience: What is it? How is it measured? Does it affect loyalty? Journal of Marketing, 73, 52-68.

Burnkrant, R. E., \& Unnava, H. R. (1995). Effects of self-referencing on persuasion. Journal of Consumer Research, 22(1), 17-26.

Buil, I., de Chernatony, L., \& Martínez, E. (2008). A cross-national validation of the consumer-based brand equity scale. Journal of Product \& Brand Management, 17(6), 384-392.

Chin, W. W. (1998a). Commentary: Issues and opinion on structural equation modeling. MIS Quarterly, 22(1), 7-16.

Chin, W. W. (1998b). The partial least squares approach for structural equation modeling. In G. A. Marcoulides (Ed.), Modern methods for business research (pp. 295-336). Lawrence Erlbaum Associates.

Chin, W. W. (2010). How to write up and report PLS analyses. In V. Esposito Vinzi, W. W. Chin, J. Henseler, and H. Wang (Eds.), Handbook of partial least squares (pp. 655-690). New York: Springer.

Cobb-Walgren, C. J., Ruble, C. A., \& Donthu, N. (1995). Brand equity, brand preference, and purchase intent. Journal of Advertising, 24(3), 25-40.

Davis, J. A. (2009). Competitive success, how branding adds value wiley. John Wiley \& Sons.

Ekström, K. M., \& Brembeck, H. (2004). Elusive consumption. Berg Publishers.

Farquhar, P. (1989). Managing brand equity. Marketing Research, 1, 24-33.

Forgas, J. P. (1981). Affective and emotional influences on episode representations. Social Cognition: Perspectives on Everyday Understanding, 165-180.

Gefen, D., Straub, D. W., \& Boudreau, M. C. (2000). Structural equation modeling and regression: Guidelines for research practice. Communications of the Association for Information Systems Citeseer, 4(7), 1-77.

Gorn, G. J., Chattopadhyay, A., Yi, T., \& Dahl, D. W. (1997). Effects of color as an executional cue in advertising: They're in the shade. Management Science, 43(10), 1387-1400.

Grundey, D. (2008). Experiental marketing vs. traditional marketing: Creating rational and emotional liaisons with consumers. The Romanian Economic Journal, 29, 133-151.

Ha, H. Y., \& Perks, H. (2005). Effects of consumer perceptions of brand experience on the web: Brand familiarity, satisfaction and brand trust. Journal of Consumer Behaviour, 4, 438-452.

Hoe, S. L. (2008). Issues and procedures in adopting structural equation modeling technique. Journal of Applied Quantitative Methods, 3(1), 76-83.

Hair, J. F., Black, W. C., Babin, B. J., \& Anderson, R. E. (2010). Multivariate data analysis (7th ed.). Englewood Cliffs: Prentice Hall.

Holbrook, M. B., \& Hirschman, E. C. (1982). The experiential aspects of consumption: Consumer fantasies, feelings, and fun. Journal of Consumer Research, 9(2), 132-140.

Hultén, B., Broweus, N., \& Van Dijk, M. (2009). What is sensory marketing? (pp. 1-23). Palgrave Macmillan UK.

Iglesias, O., Singh, J. J., \& Batista-Foguet, J. M. (2011). The role of brand experience and affective commitment in determining brand loyalty. Journal of Brand Management, 18(8), 570-582.

Keller, K. L. (1987). Memory factors in advertising: The effect of advertising retrieval cues on brand evaluations. The Journal of Consumer Research, 14, 316-333.

Keller, K. L. (1993). Conceptualizing, measuring, and managing customer-based brand equity. The Journal of Marketing, 57(1), $1-22$.

Keller, K. L. (2003). Strategic brand management: Building, measuring, and managing brand equity (2nd ed.). NJ Ciffs, Englewoods: Prentice Hall.

Keller, K. L., \& Lehmann, D. R. (2006). Brands and branding: Research findings and future priorities. Marketing Science, $25,740$. 
Kim, J. (2003). Affective and cognitive brand conviction: Making loyal relationships. University of Florida.

Kline, R. B. (2015). Principles and practice of structural equation modeling. New York: Guilford Publications.

Krishnan, H. S. (1996). Characteristics of memory associations: A consumer-based brand equity perspective. International Journal of Research in Marketing, 13, 389-405.

Lancaster, L. C., \& Stillman, D. (2010). The M-factor: How the Millennial generation is rocking the workplace. Harper Collins (e-books).

Lassar, W., Mittal, B., \& Sharma, A. (1995). Measuring customer-based brand equity. Journal of Consumer Marketing, 12, 11-19.

Malhotra, N., Dash, S., Kumar, S. R., \& Chandra, P. P. (2013). The nature and antecedents of brand equity and its dimensions. Marketing Intelligence \& Planning, 31(2), 141-159.

Mandel, N., \& Johnson, E. J. (2002). When web pages influence choice: Effects of visual primes on experts and novices. Journal of Consumer Research, 29(2), 235-245.

Meyers-Levy, J., Peracchio, L. A., \& Peracchio, L. (1995). How the use of color in advertising affects attitudes: The influence of processing motivation and cognitive demands. Journal of Consumer Research, 22, 121-138.

Rendell, M., Linde, K. V., \& Yildirim, L. (2011). Millennials at work-Perspectives from a new generation. Retrieved from www.pwc.com/managingpeople2020

Morrison, S., \& Crane, F. G. (2007). Building the service brand by creating and managing an emotional brand experience. Journal of Brand Management, 14, 410-421.

Niedenthal, P. M., \& Halberstadt, J. H. (2001). 15. Grounding categories in emotional response. Feeling and thinking: The role of affect in social cognition, 357.

O’Shaughnessy, J. (1992). Explaining buyer behavior: Central concepts and philosophy of science issues. New York: Oxford University Press.

Kotler, P., \& Armstong, G. (2012). Principles of marketing (14th ed.). England: Pearson Education Limited.

Pine, B. J., \& Gilmore, J. H. (1999). The experience economy: Work is theatre \& every business a stage. Cambridge: Harvard Business Press.

Podsakoff, P. M., MacKenzie, S. B., Lee, J. Y., \& Podsakoff, N. P. (2003). Common method biases in behavioral research: A critical review of the literature and recommended remedies. Journal of Applied Psychology, 88(5), 879-903.

Price Water Copperhouse (PWC). (2009). Malaysia's gen $Y$ unplugged. Retrieved from http://pwc.com/en_my/my/assets/publications/gen

Ratneshwar, S., \& Mick, D. G. (2005). Inside consumption: Consumer motives, goals, and desires. New York: Psychology Press.

Rose, S. (1993). The making of memory: From molecules to mind. Random House.

Schmitt, B. H. (1999). Experiential marketing: How to get customers to sense, feel, think, act and relate to your company and brands. New York: The Free Press.

Sekaran, U., \& Bougie, R. (2010). Research methods for business: A skill building approach (5th ed.). London: John Willey \& Sons Ltd.

Simon, C. J., \& Sullivan, M. W. (1993a). The measurement and determinants of brand equity: A financial approach. Marketing Science, 12, 28-52.

Simon, C. J., \& Sullivan, M. W. (1993b). A financial approach to estimating firm-level brand equity and measuring the impact of marketing events. Cambridge.

Smith, R. E., \& Swinyard, W. R. (1983). Attitude-behavior consistency: The impact of product trial versus advertising. Journal of Marketing Research, 20(3), 257-267.

Srivastava, R. K., \& Shocker, A. D. (1991). Brand equity: A perspective on its meaning and measurement. Marketing Science Institute.

Tenenhaus, M., Vinzi, V. E., Chatelin, Y. M., \& Lauro, C. (2005). PLS path modeling. Computational Statistics \& Data Analysis, 48(1), 159-205.

Veryzer Jr, R. W., \& Hutchinson, J. W. (1998). The influence of unity and prototypicality on aesthetic responses to new product designs. Journal of Consumer Research, 24(4), 374-394.

Wetzels, M., Odekerken-Schröder, G., \& Van Oppen, C. (2009). Using PLS path modeling for assessing hierarchical construct models: Guidelines and empirical illustration. MIS Quarterly, 33(1), 177-195.

Williams, K. C., \& Page, R. A. (2010). Marketing to the generations. Journal of Behavioral Studies in Business, 3(4), 8-10.

Wood, L. (2000). Brands and brand equity: Definition and management. Management Decision, 38, 662-669. 
Xu, J. B., \& Chan, A. (2010). A conceptual framework of hotel experience and customer-based brand equity: Some research questions and implications. International Journal of Contemporary Hospitality Management, 22, 174-193.

Yoo, B., \& Donthu, N. (2001). Developing and validating a multidimensional consumer-based brand equity scale. Journal of Business Research, 52(1), 1-14.

Zajonc, R. (2000). Feeling and thinking: Closing the debate on the primacy of affect. Feeling and thinking: The role of affect in social cognition, pp. 31-58.

Zaltman, G. (2003). How customers think: Essential insights into the mind of the market. New York: Harvard Business Press.

Zarantonello, L., \& Schmitt, B. H. (2010). Using the brand experience scale to profile consumers and predict consumer behaviour. Journal of Brand Management, 17, 532-540. 